\title{
Time course of zinc deprivation-induced alterations of mice behavior in the forced swim test
}

\author{
Katarzyna Młyniec 1,2,5, Claire Linzi Davies ${ }^{4}$, Bogusława Budziszewska ${ }^{2,5}$, \\ Włodzimierz Opoka ${ }^{3}$, Witold Reczyński ${ }^{6}$, Magdalena Sowa-Kućma ${ }^{5}$, \\ Urszula Doboszewska ${ }^{5}$, Andrzej Pilc ${ }^{5,7}$, Gabriel Nowak ${ }^{1,5}$ \\ ${ }^{1}$ Department of Pharmacobiology, ${ }^{2}$ Department of Toxicology, ${ }^{3}$ Department of Inorganic Chemistry, \\ Jagiellonian University Medical College, Medyczna 9, PL 30-688 Kraków, Poland \\ ${ }^{4}$ Strathclyde Institute of Pharmacy and Biomedical Sciences, University of Strathclyde, Glasgow, Scotland, UK \\ ${ }^{5}$ Institute of Pharmacology, Polish Academy of Sciences and Center of Excellence in Neuropsychopharmacology, \\ Smętna 12, PL 31-343 Kraków, Poland \\ ${ }^{6}$ Faculty of Material Science and Ceramics, AGH University of Science and Technology, Mickiewicza 30, \\ PL 30-059 Kraków, Poland \\ ${ }^{7}$ Faculty of Health Sciences, Jagiellonian University Medical College, Michałowskiego 20, PL 31-126 Kraków, \\ Poland
}

Correspondence: Katarzyna Młyniec, e-mail: katarzyna.mlyniec@uj.edu.pl

\begin{abstract}
:
Background: Zinc is an important trace element essential for numerous bodily functions. It is believed that a deficiency of zinc can lead to various conditions, including depression, on which this study is focused. It is still not known if hypozincemia leads to the development of depression or whether zinc deficiency is a result of depression. It is hypothesized that zinc may be a therapeutic agent or supplement that would help to reverse the symptoms of this disease.

Methods: In the present study, the behavior of mice was assessed 2, 4, and 10 weeks following administration of a zinc deficient diet. To evaluate animal activity we used the forced swim test (FST).

Results: After 2-week zinc deprivation we demonstrated a significant reduction in the immobility time. However, after 4 and 10 weeks of zinc deprivation the mice exhibited an increased immobility time. There were no changes in locomotor activity at each time period. After 2-, 4- and 10-week zinc deprivation and the subsequent FST, serum zinc concentration was decreased and determined to be 59, 61 and 20\%, respectively, compared with appropriate controls. The serum corticosterone concentration in mice after 2-, 4and 10-week zinc deprivation and subjected to the FST was also assessed, whereby the differences between the control and experimental animals were demonstrated (increased by: 11, 97 and 225\%, respectively).

Conclusions: The obtained results indicate that zinc deprivation induced "pro-depressive" behavior (after the initial period of "antidepressive" behavior). This pro-depressive behavior correlates with enhanced serum corticosterone concentration.
\end{abstract}

\section{Key words:}

zinc deficiency, serum concentration, zinc, corticosterone, HPA axis, depression, FST 


\section{Introduction}

Considered to be one of the most common psychopathological disorders, depression can affect one in six men and one in four women, with varying degrees of severity and recurrence [11]. It is a poorly understood mental condition characterized by low self esteem, immune system malfunction [18], anorexia and low motivation, along with social implications [3].

It is believed that the metal element zinc plays a role in this disorder [40, 47, 52]. Zinc is an important element which is essential for numerous bodily processes, including brain function, DNA replication and protein synthesis; more than 300 proteins are known to require zinc $[18,48]$.

Zinc homeostasis is maintained strictly by the blood-brain barrier and blood-cerebrospinal barrier. It is hypothesized that proteins requiring zinc for function are responsive to changes in dietary zinc; decreased levels of zinc have been observed in extracellular [47] but not in whole hippocampal tissue during zinc deficiency. An alteration in zinc homeostasis can result in clinical depression, changes in behavior and mental function. A reduced blood zinc level is observed in major depression and is proposed as a state marker of depression [16, 33]. Zinc is thought to be an inhibitor at the NMDA receptor, which itself may be involved in the psychopathology and therefore a target for the treatment of depression $[8,25,40]$. The relationship between neuronal function and behavior is vital to the understanding of the dynamics of complex mental disorders such as depression and anxiety. Previous studies have indicated that zinc plays a role in anxiolytic and antidepressant therapy; this has been demonstrated in preclinical tests including the elevated plus maze test and four-plates test [28], forced swim test (FST) $[12,13,24,30]$ and tail suspension test (TST) $[8,30]$.

Up to $50 \%$ of the population is thought to have inadequate levels of zinc in their blood in both developed and underdeveloped countries worldwide and may be a possible reason for some symptoms of depression [2]. Zinc enhances the antidepressant-like effects of conventional antidepressants (including imipramine) in the FST, TST and chronic unpredictable stress (CUS) model [5, 8, 39, 41]. Of great concern are recent findings coming from clinical studies in which zinc supplementation enhances the efficacy of antidepressant therapy, particularly in treatment resistant patients [22, 32].
It has been suggested that the stress is related to an increase in glucocorticoid concentration [38, 47, 52]. The hypothalamus-pituitary-adrenal (HPA) system is the final common pathway in the mediation of the stress response [1]. It is thought that zinc deficiency can cause alterations of the HPA axis in depression. The hypothalamic overproduction of the corticotropin-releasing hormone overstimulating adrenocorticotropin in the anterior lobe of the pituitary [56] results in excess production of the glucocorticoid corticosterone in rodents. This dysregulation seems to be an important factor in the pathogenesis of depression $[42,45,47,51]$.

The aim of this study was to determine whether administration of a diet deficient in zinc would cause "depressive behavior" and if such behavioral alterations would correlate with serum corticosterone and zinc concentration. The FST was used to assess the behavioral changes ("depressive state") of the animals during zinc deficiency over a period of 2, 4 and 10 weeks.

\section{Materials and Methods}

\section{Animals}

Male CD-1 mice (3 weeks old) were housed under the standard laboratory conditions with a natural daynight cycle, a temperature of $22 \pm 2{ }^{\circ} \mathrm{C}$ and the humidity at $55 \pm 5 \%$ as well as access to food and water $a d$ libitum. Each experimental group consisted of 7-8 animals. All of the procedures were conducted according to the National Institute of Health Animal Care and Use Committee guidelines, which were approved by the Ethical Committee of the Jagiellonian University Medical College, Kraków.

\section{Zinc deficient diet}

Control (33.5 $\mathrm{mg} \mathrm{Zn} / \mathrm{kg})$ and zinc deficient $(0.2 \mathrm{mg}$ $\mathrm{Zn} / \mathrm{kg}$ ) diets were purchased from MP Biomedicals (France). Mice were assigned to one of six different groups according to the diet and duration of the diet administration (Fig. 1). 


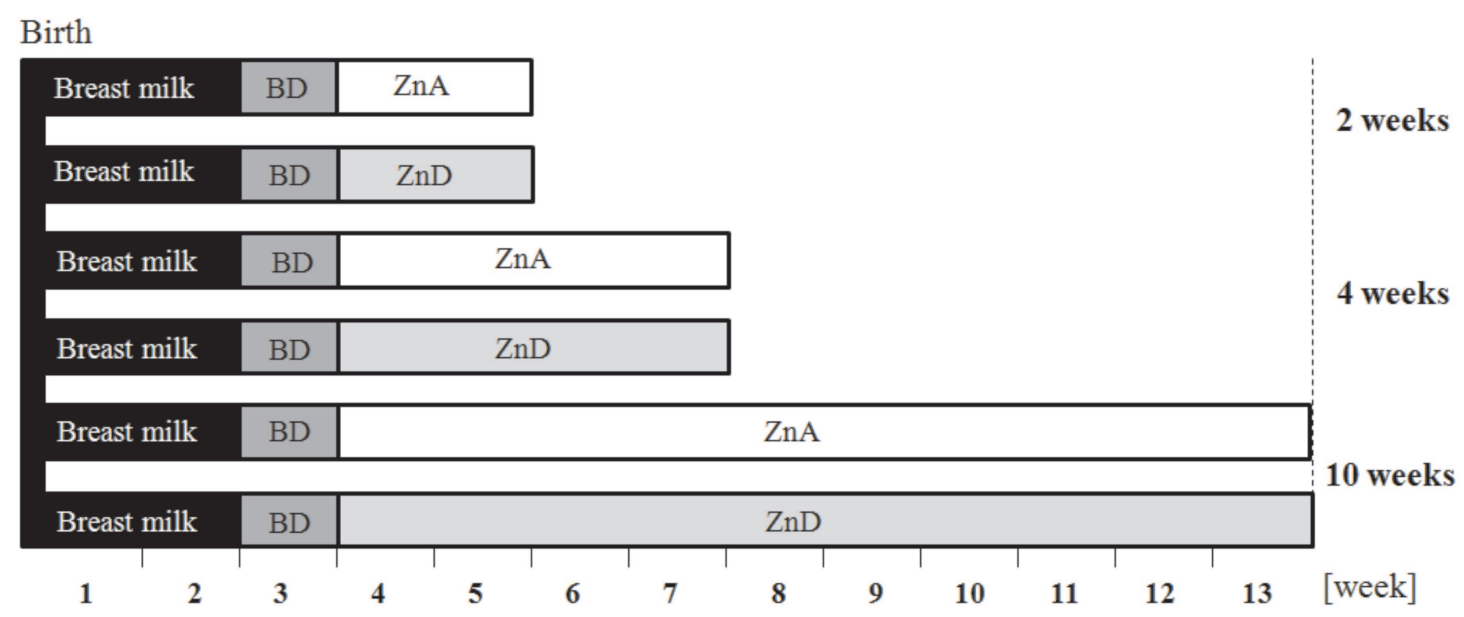

Fig. 1. Schedule of feeding procedure of animals used in the study. BD - basic diet (46.6 mg Zn/kg), ZnA - zinc adequate diet (33.5 mg Zn/kg),

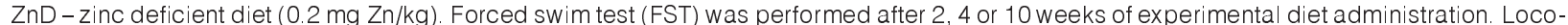
motor activity was examined $24 \mathrm{~h}$ before FST. Twenty four hours after FST animals were decapitated and serum collected

\section{Behavior}

FST

The studies were carried out on mice according to the method of Porsolt et al. [29]. The animals were dropped individually into glass cylinders (height $25 \mathrm{~cm}$, diameter $10 \mathrm{~cm}$ ) containing $10 \mathrm{~cm}^{3}$ of water, maintained at $23-25^{\circ} \mathrm{C}$. The mice were left in the cylinder for $6 \mathrm{~min}$. After the first $2 \mathrm{~min}$, the total duration of immobility was measured during the following 4-min test. The mouse was judged to be immobile when it remained floating passively in the water.

\section{Locomotor activity}

The locomotor activity of the mice was measured with photoresistor actometers (circular cages, diameter $25 \mathrm{~cm}$, two light beams). The animals were individually placed in an actometer and activity was then measured between 2 and $6 \mathrm{~min}$. The number of crossings of the light beams by the mice was then recorded as the locomotor activity.

\section{Blood sampling and biochemical assays}

Serum corticosterone levels were estimated $24 \mathrm{~h}$ after the FST at 8:00 a.m. The animals were then sacrificed under non-stressful conditions by rapid decapitation and the blood was collected. The serum was separated by centrifugation in a refrigerated centrifuge at $800 \times$ $\mathrm{g}$ for $15 \mathrm{~min}$ and stored at $-20^{\circ} \mathrm{C}$ until the assay.

\section{Corticosterone assay}

Corticosterone was extracted from the serum using ethanol and was measured by a radioimmunological method. The ethanol serum extracts were dried under a nitrogen stream, dissolved in $0.1 \mathrm{ml}$ of $0.05 \mathrm{mM}$ phosphate buffer, $\mathrm{pH} 7.0$, containing $0.9 \% \mathrm{NaCl}$ and $0.1 \%$ gelatin (Sigma Chemical Co.), and were incubated with a $0.1 \mathrm{ml}$ solution of $1,2,6,7-\left[{ }^{3} \mathrm{H}\right]$-corticosterone (20,000 dpm/sample; Radiochemical Centre, Amersham, s.a. $85 \mathrm{Ci} / \mathrm{mmol}$ ) and with a $0.1 \mathrm{ml}$ solution of a corticosterone antibody (Chemicon) for $16 \mathrm{~h}$ at $4^{\circ} \mathrm{C}$. Free and bound corticosterone were separated using dextran-coated charcoal. The samples were incubated for $10 \mathrm{~min}$ at $4^{\circ} \mathrm{C}$ with $0.2 \mathrm{ml}$ of $0.05 \%$ dextran (Dextran T 70, Pharmacia) and $0.5 \%$ charcoal (activated, Sigma) suspension. After centrifugation at $1,000 \times \mathrm{g}$ for $20 \mathrm{~min}, 0.3 \mathrm{ml}$ of the supernatant was placed in a scintillator and the radioactivity was measured in a $\beta$-counter (Beckmann LS 335). The crossreactivities of the used antiserum with 11-dehydrocorticosterone and deoxycorticosterone were 0.67 and $1.5 \%$, respectively, whereas those of other steroids were below $0.01 \%$. The corticosterone content was calculated using a log-logit transformation. The assay sensitivity was $10 \mathrm{pg} /$ tube. Intra- and inter-assay coefficients of the variation were lower than $5 \%$ and $8 \%$, respectively. 


\section{Zinc assay}

Due to the low volumes, no sample pretreatment procedures were applied. The thawed samples were thoroughly mixed as these were not homogenous, and analyzed directly by means of the atomic absorption spectrometry (AAS) method. In some instances (the samples with the smallest volume), the electrothermal technique (ET AAS) was used, while for the samples of higher volume, the flame technique (F AAS) was applied.

For both techniques, the determination procedure and instrumental parameters were optimized to obtain the highest possible sensitivity. On the other hand, the procedure was prepared in a way to prevent any possible contamination of the sample with the analyte from the environment. Only quadruple distilled water was used for both the sample and preparation of the standard solutions.

The detection limits of $\mathrm{Zn}$ determination in the F AAS and ET AAS techniques were $3.6 \mu \mathrm{g} / 1$ and $0.07 \mu \mathrm{g} / \mathrm{l}$, respectively. Precision of the measurements was less than $7 \%$ (RSD), and it was a direct result of inhomogenity of the analyzed samples. The accuracy of measurements was checked by means of comparative analysis of a chosen digested sample via the F AAS and voltammetry (ASV) methods. The difference between the obtained results was less than $2 \%$. To determine $\mathrm{Zn}$ concentration, a Perkin Elmer Model 3110 (USA) spectrometer was used; flame analysis was made in an air-acetylene flame, HCL lamp, wavelength $213.9 \mathrm{~nm}$, slit $0.7 \mathrm{~nm}$. The electrothermal analysis was conducted by the use of a Perkin Elmer HGA 600 instrument, at the same spectral conditions, using a pyrolytic coated graphite furnace.

\section{Data analysis}

The data obtained were evaluated by Student's $t$-test. All the results are presented as the mean \pm SEM; $p<$ 0.05 was considered to be statistically significant.

\section{Results}

\section{Body weight}

The body weight of mice at the beginning of the experiment (before any diet) was $15.5 \pm 2.2 \mathrm{~g}$. There was a significant difference in body weight in zinc- deficient animals when compared to the control animals after 2 weeks of diet $(33.6 \pm 1.0 \mathrm{~g}$ for the control and $24.7 \pm 1.2 \mathrm{~g}$ for the zinc-deficient group, $\mathrm{p}<$ $0.0001)$ and 4 weeks $(42.3 \pm 1.1 \mathrm{~g}$ for the control and $30.0 \pm 1.3 \mathrm{~g}$ for the zinc-deficient group, $\mathrm{p}<0.0001$ ) of the diet. After 10 weeks of the diet, a small insignificant difference was observed in the zinc-deficient animals when compared to the control group (55.8 \pm $2.6 \mathrm{~g}$ and $49.2 \pm 2.1 \mathrm{~g}$, respectively).
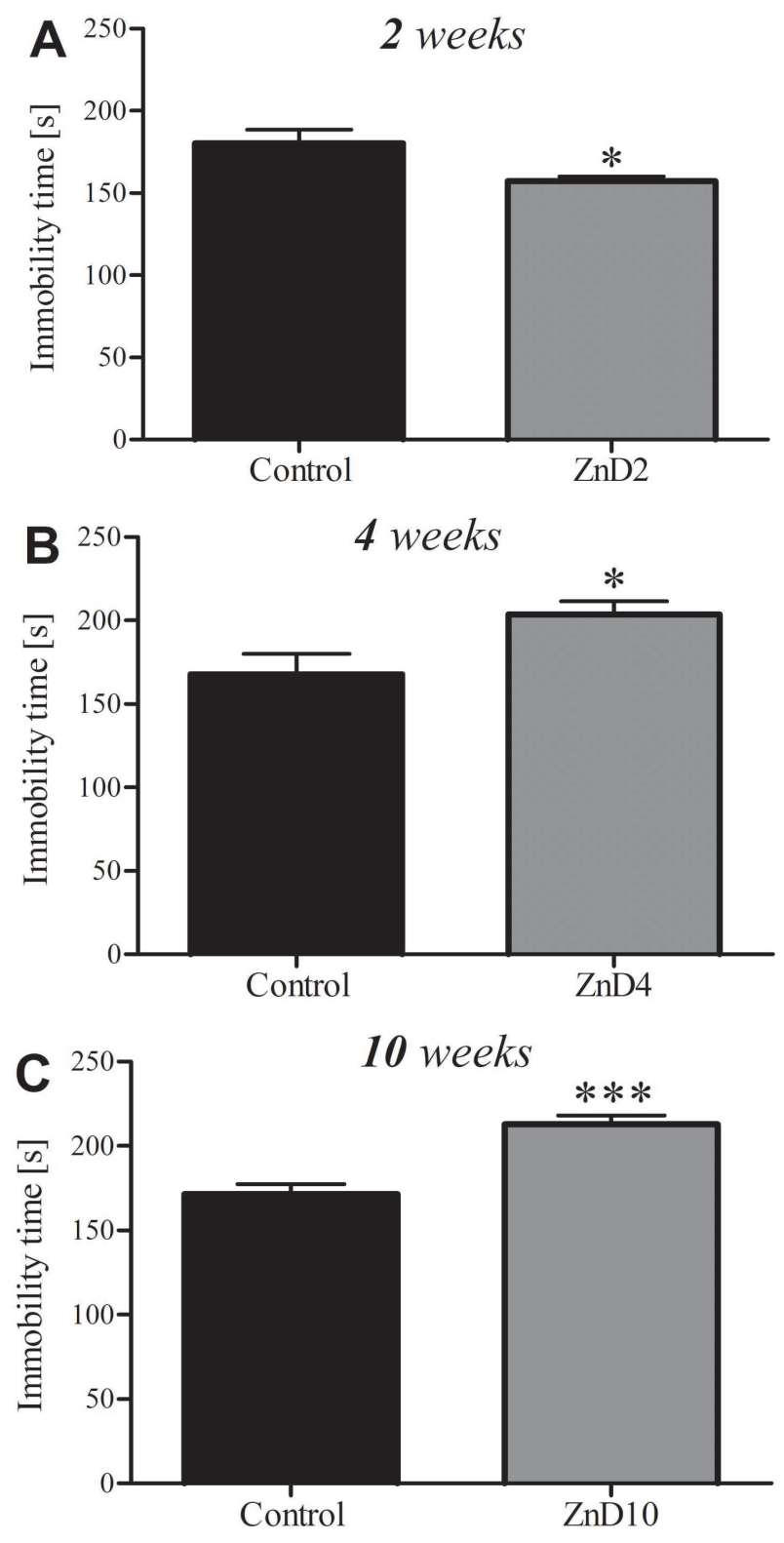

Fig. 2. Influence of administration of 2- (A), 4- (B) and 10- (C) week zinc deficient diet on immobility time in the forced swim test. ZnD zinc deficient diet. Values are expressed as the mean \pm SEM. ${ }^{*} p<$ $0.05 ;{ }^{* * *} \mathrm{p}<0.001$ vs. control 
FST

The effects of zinc deficiency on the total duration of immobility time in mice after a 2 -week zinc deficient diet are shown in Figure 2A. The zinc deficient diet after 2 weeks significantly (by $13 \%$ ) reduced immobility time in the test.

The effects of zinc deficiency on the total duration of immobility time in mice after a 4-week zinc deficient diet are shown in Figure 2B. The zinc deficient diet after 4 weeks significantly (by $21 \%$ ) increased the immobility time.

The effects of zinc deficiency on the total duration of immobility time in mice after a 10 -week zinc deficient diet are shown in Figure 2C. The zinc deficient diet after 10 weeks significantly (by 24\%) increased immobility time in the test.

\section{Locomotor activity}

The effects on spontaneous locomotor activity in mice are shown in Table 1. There were no changes in locomotor activity in all of the groups, either control or zinc-deficient.

\section{Serum corticosterone level}

The effects of zinc deprivation on the corticosterone level in mice subjected to FST are shown in Figure 3. There were no significant differences ( $11 \%$ increase) in corticosterone concentration between the control and zinc deficient animals after 2 weeks. A significant increase in corticosterone was observed in mice after the 4- (by 97\%) and 10-week (by 225\%) administration of the zinc deficient diet.

Tab. 1. The influence of 2,4 and 10 weeks' administration of a zinc deficient diet on locomotor activity of mice measured during 4-min period

\begin{tabular}{lcc}
\hline & Control & Zinc deficiency \\
\hline 2 weeks & $104.7 \pm 6.9$ & $102.7 \pm 12.1$ \\
4 weeks & $109.3 \pm 11.3$ & $88.3 \pm 5.6$ \\
10 weeks & $65.8 \pm 9.6$ & $61.7 \pm 10.3$ \\
\hline
\end{tabular}

Values are the means \pm SEM of 7 animals per group
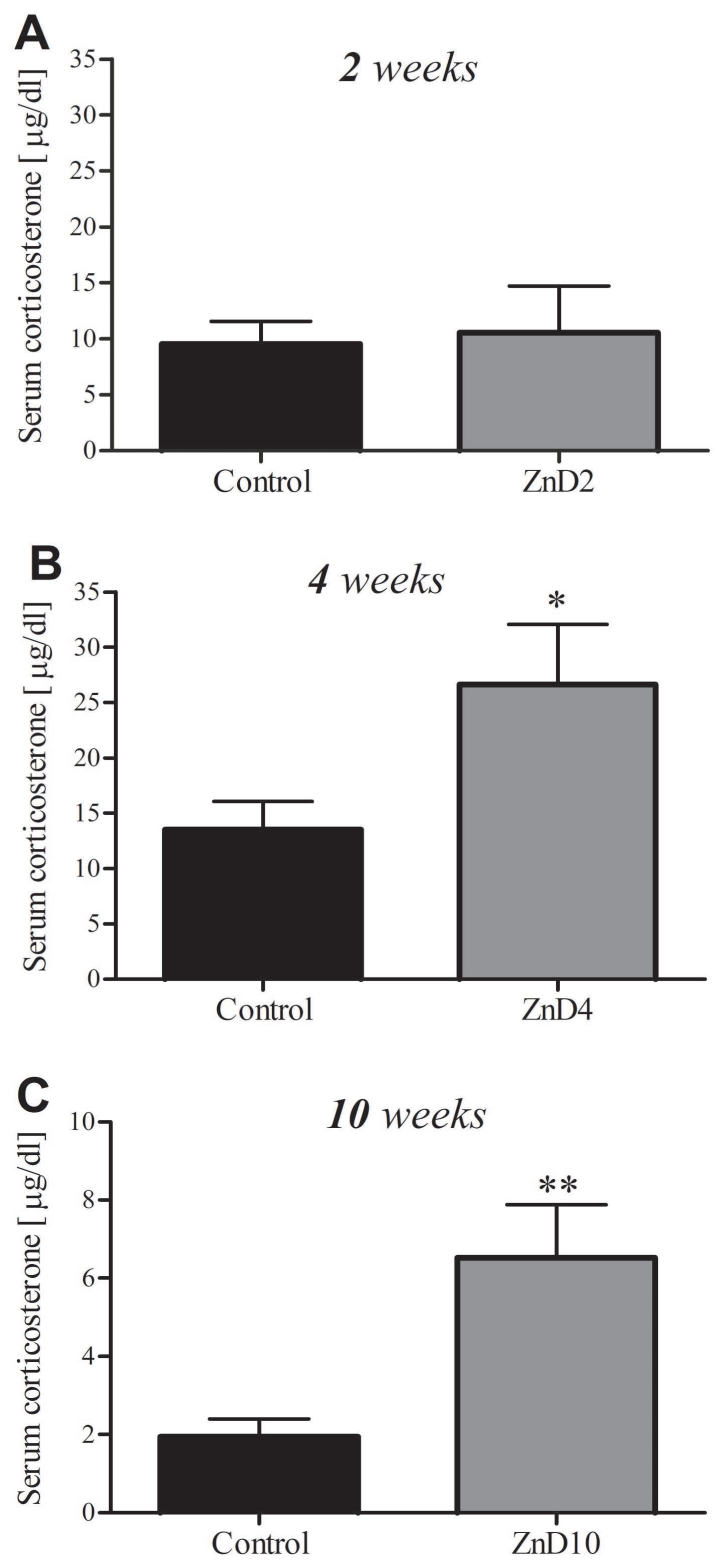

Fig. 3. Influence of administration of a 2- (A), 4- (B) and 10- (C) week zinc deficient diet on serum corticosterone concentration. ZnD - zinc deficient diet. Values are expressed as the mean \pm SEM; * $p<0.05$; ${ }^{* *} p<0.01$ vs. control

\section{Serum zinc concentration}

The effects of zinc deprivation on the serum zinc level in mice subjected to FST are shown in Figure 4. A significant reduction in zinc concentration was demonstrated by 2 (59\% of control) and 4 (61\% of control) weeks of administration of the zinc deficient diet. After 10 weeks of the zinc deficient diet, serum zinc was significantly reduced by only $20 \%$. 

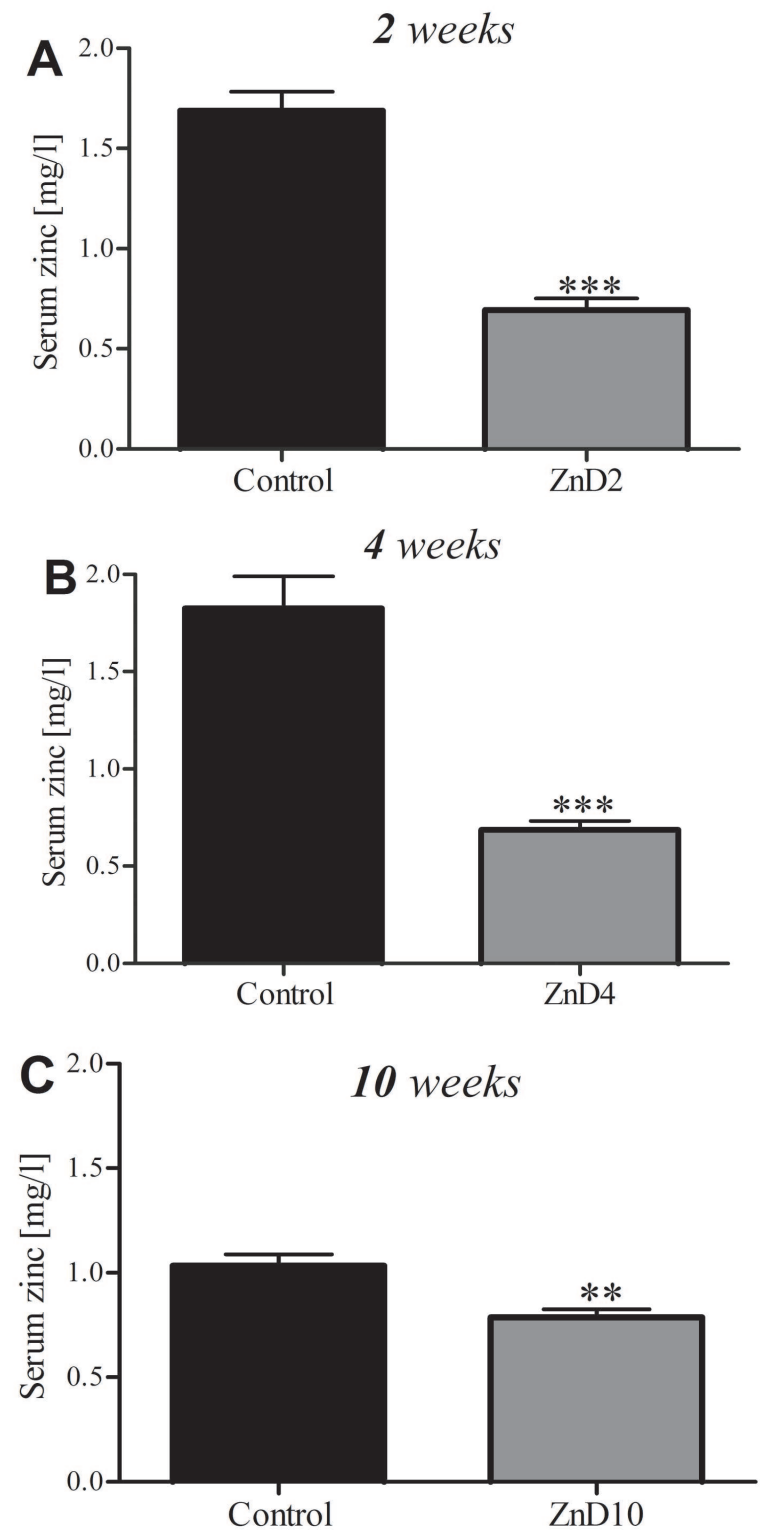

Fig. 4. Influence of administration of a 2- (A), 4- (B) and 10- (C) week zinc deficient diet on serum zinc concentration. $\mathrm{ZnD}-$ zinc deficient diet. Values are expressed as the mean \pm SEM. ${ }^{* *} p<0.01 ;{ }^{* *} p<$ 0.001 vs. control

\section{Discussion}

The antidepressant activity of zinc was demonstrated in animal preclinical tests and models of depression (FST [13, 30], TST [30], olfactory bulbectomy (OB) [24], CUS [5, 6] and chronic mild stress (CMS) [36]). Zinc can enhance the antidepressant effect of drugs when given as an adjunct to ineffective doses of anti- depressants $[5,8,12,39,41]$. Moreover, the activity of zinc in augmentation therapy was demonstrated in major depression [22, 32], whilst diminished blood zinc levels are concurrent with depression [17-19, 31,33].

For over two decades, neuroscience has implicated zinc in depression, leading to the notion that zinc deficiency is involved in the pathophysiology of this disease. The main problem is that it is not known if low zinc levels lead to the development of depression or whether zinc deficiency is a result of depression (see [7] for discussion). One of the first reports about depressive behavior in zinc deficiency was demonstrated by Suliman et al. in 1988, whose paper describes conditions such as skin lesions, wool eating, flexed knees and a markedly stiff gait in sheep [37].

In the present study, we examined the changes in behavior at different times during the administration of a zinc deficient diet in mice. Firstly, similar to our previously published observations [20], we observed a lower body weight gain in zinc deficiency groups, which received zinc deficient diet for 2 and 4 weeks but not for 10 weeks when compared to the control. Although, a previous study suggests that zinc deficiency causes anorexia [14], decreased food intake does not seem to be the cause of depression-like behavior, because the immobility time (in the FST) was found to be significantly increased in zinc-deficient yet not pair-fed rats [57].

After the first two weeks of a zinc-deficient diet, mice surprisingly exhibited antidepressant-like behavior in the FST. Similar effect was demonstrated previously in the tail suspension test in mice [20]. Then, after the 4-week zinc deprivation, the animals exhibited "pro-depressive behavior" (prolonged immobility time). The differences between 2 and 4 weeks of zinc deprivation can be related to the brain zinc concentration described by Takeda and coworkers. In vivo micro-dialysis experiments indicated that extracellular zinc in the hippocampus does not significantly change in young rats after 2 -week zinc deprivation [44], but decreases in young rats after 4-week zinc deprivation [43]. Furthermore, the same authors indicated that histochemically reactive zinc (Timm's stain) decreases after 4-week zinc deficiency in mice [49]. Another possible mechanism involved in the differences between 2- and 4-week zinc deficient groups is a compensative mechanism, occurring after a 2-week zinc deficient diet which contributes to the changes in the zinc levels. Metallothioneins are proteins that are able to bind up to seven atoms of zinc 
temporarily. Thus they bind zinc when it is in excess in the cytoplasm and release it when there is a shortage $[21,55]$, however, this issue needs to be examined in future research.

There were also differences between 4- and 10week zinc deficient animals. After a 10-week diet, a higher increase in depressive behavior was observed compared to that following a 4-week zinc deficient diet. It is thought that an increased duration of zinc deficiency can lead to the development of a depressive disorder [15]. Halsted et al. [10] was the first to describe that prolonged zinc deficiency results in neuropsychological changes such as emotional instability, irritability and depression.

No effects of zinc deficiency on locomotor activity in each time period were observed, however, control mice after 10 weeks of diet showed a decrease in activity counts compared to mice after 2 and 4 weeks of diet. This may be associated with age of mice. These same changes were observed in our previous study. Control animals after 4 weeks of diet showed higher activity than animals after 6 weeks of the control diet [26].

The glutamate hypothesis of depression was proposed by Skolnick et al. [34]. Based on the antidepressant-like activity of glutamate receptor (firstly the NMDA) antagonists, a link between the hyperactivity of the glutamate system and depression was observed $[34,35,54]$. Zinc is an antagonist of the NMDA receptor and exhibits antidepressant-like activity in rodent tests and models of depression [23, 27, 40]. Moreover, a higher glutamate concentration in zincdeficient animals compared to control animals was demonstrated [45, 48]. Extracellular glutamate accumulation in the hippocampus is also potentiated by glucocorticoids [47]. During zinc deficiency, chronic alteration of corticosterone secretion and a decrease in synaptic zinc levels seems to be linked to the excitability of glutamatergic neurons in the hippocampus [45].

After a 2-, 4- and 10-week zinc deficient diet and following the FST, we also investigated serum corticosterone concentration. The first period of zinc deficiency ( 2 weeks) induced an insignificant $11 \%$ increase, while the next period induced an increase over $95 \%$. Thus it can be concluded that zinc deficiency is correlated with disturbances of the HPA axis. Several papers report a rise in corticosterone levels after 2-week [46, 47, 53, 57] and 3-week zinc deprivation [4]. The increased corticosterone concentration after 2 weeks of zinc deficiency was correlated with a rise in the immobility time in the FST observed in rats but not in mice [57]. It is not known if the increase in immobility time is a result of zinc deficiency due to a rise in glucocorticoid concentration. Two-week exposure to corticosterone elicited an increase in the immobility time in the FST, suggesting that neuropsychological symptoms in zinc deficiency may be associated with abnormal corticosterone secretion [53]. Our data show a reduction in immobility after 2 weeks of zinc deprivation. The differences observed between the above results may be due to another strain of mouse or different zinc concentrations in the diet (44 $\mathrm{mg} \mathrm{Zn} / \mathrm{kg}$ for the control and $2.7 \mathrm{mg} \mathrm{Zn} / \mathrm{kg}$ for zinc deficient animals) compared to the present study (control $33.5 \mathrm{mg} \mathrm{Zn/kg}$, zinc deficiency $0.2 \mathrm{mg}$ $\mathrm{Zn} / \mathrm{kg}$ ). The lower serum corticosterone level observed in control animals after 10 weeks of diet compared to animals after 2 and 4 weeks of control diet was probably caused by habituation to human presence. Mice fed for 10 weeks with control diet were handled longer than mice receiving diet for 2 and 4 weeks. It is also possible that young mice are more susceptible to activation of the HPA axis under stress conditions than older mice, but this requires further studies.

The measurement of serum zinc concentration brought somehow surprising results. The first two periods of zinc deprivation ( 2 or 4 weeks) reduced serum zinc by over $50 \%$, while after 10 weeks of zinc deprivation a small reduction of $20 \%$ was seen. Our data, following 2 or 4 weeks of zinc deprivation, resembles that of El Hendy et al. [9] who showed a 17 to $78 \%$ reduction in serum zinc concentration in rats. Takeda et al. [47] also demonstrated a less than 50\% reduction after 1 - and 2-week zinc deprivation. It is possible that after the extended period of zinc deprivation adaptive mechanisms may redistribute zinc from different pools (e.g., the liver) to the blood and/or the physiological reduction in blood zinc concentration during lifetime may account for the lower zinc concentration observed between the control and zinc-deficient animals at 12 weeks. Moreover, in our experiments stress induced by FST may also participate in such differences in the serum zinc concentrations. It should be added that control mice after 10 weeks of diet showed much lower serum zinc level than animals after 2 and 4 weeks of control diet. This may be associated with age of mice. Zinc concentration in the brain remains constant in aged animals, whereas serum zinc level is significantly lower in 
aged than in young animals [50]. Thus, the present data questions serum zinc as a universal marker of zinc deficiency, and this issue needs to be examined extensively in the future.

\section{Conclusions}

The present results indicate that zinc deprivation induced "pro-depressive" behavior in the FST in mice (after the initial period of "antidepressive" behavior). This pro-depressive behavior tends to correlate with enhanced serum corticosterone concentration, but not with the reductions in serum zinc concentration.

\section{Acknowledgments:}

This study was partially supported by Grant POIG

01.01.02-12-004/09, Funds for Statutory Activity of the Institute of Pharmacology, Polish Academy of Sciences and Jagiellonian University Medical College, Kraków, Poland.

\section{References:}

1. Bao AM, Meynen G, Swaab DF: The stress system in depression and neurodegeneration: Focus on the human hypothalamus. Brain Res Rev, 2008, 57, 531-553.

2. Brown KH, Wuehler SE, Peerson JM: The importance of zinc human nutrition and estimation of the global prevalence of zinc deficiency. Food Nutr Bull, 2001, 22, 113-125.

3. Burcusa SL, Iacono WG: Risk for recurrence in depression. Clin Psychol Rev, 2007, 27, 959-985.

4. Chu Y, Mouat MF, Harris RBS, Coffield JA, Grider A: Water maze performance and changes in serum corticosterone levels in zinc-deprived and pair-fed rats. Physiol Behav, 2003, 78, 569-578.

5. Cieślik K, Klenk-Majewska B, Danilczuk Z, Wróbel A, Łupina T, Ossowska G: Influence of zinc suplementation on imipramine effect in a chronic unpredictable stress (CUS) model in rats. Pharmacol Rep, 2007, 59, 46-52.

6. Cieślik K, Sowa-Kućma M, Ossowska G, Legutko B, Wolak M, Opoka W, Nowak G: Chronic unpredictable stress-induced reduction in the hippocampal brainderived neurotrophic factor (BDNF) gene expression is antagonized by zinc treatment. Pharmacol Rep, 2011, 63, 537-543.

7. Cope EC, Levenson CW: Role of zinc in the development and treatment of mood disoerders. Curr Opin Clin Nutr Metab Care, 2010, 13, 685-689.

8. Cunha MP, Machado DG, Bettio LEB, Capra JC, Rodrigues ALS: Interaction of zinc with antidepressants in the tail suspension test. Prog Neuropsychopharmacol Biol Psychiatry, 2008, 32, 1913-1920.

9. El Hendy HA, Yousef MI, Abo El-Naga NI: Effect of dietary zinc deficiency on hematological and biochemical parameters and concentrations of zinc, copper, and iron in growing rats. Toxicology, 2001, 167, 163-170.

10. Halsted JA, Ronaghy HA, Abadi P: Zinc deficiency in man. Am J Med, 1972, 53, 277-284.

11. Kessler RC, McGonagle KA, Zhao S, Nelson CB, Hughes M, Eshleman S, Wittchen HU, Kendler KS: Lifetime and 12-month prevalence of DSM-III-R psychiatric disorders in the United States. Arch Gen Psychiatry, 1994, 51, 8-19.

12. Kroczka B, Brański P, Pałucha A, Pilc A, Nowak G: Antidepressant-like properties of zinc in rodent forced swim test. Brain Res Bull, 2001, 55, 297-300.

13. Kroczka B, Zięba A, Dudek D, Pilc A, Nowak G: Zinc exhibits an antidepressant-like effect in the forced swimming test in mice. Pol J Pharmacol, 2000, 52, 403-406.

14. Levenson CW: Zinc regulation of food intake: new insights on the role of neuropeptide Y. Nutr Rev, 2003, 61, 247-249.

15. Levenson CW: Zinc: the new antidepressant? Nutr Rev, 2006, 64, 39-42.

16. Maes M, D'Haese PC, Scharpe S, D'Hondt P, Cosyns P, De Broe ME: Hypozincemia in depression. J Affect Disord, 1994, 31, 135-140.

17. Maes M, De Vos N, Demedts P, Wauters A, Neels H: Lower serum zinc in major depression in relation to changes in serum acute phase proteins. J Affect Disord, 1999, 56, 189-194.

18. Maes M, Vandoolaeghe E, Neels H, Demedts P, Wauters A, Meltzer HY, Altamura C, Desnyder R: Lower serum zinc in major depression is a sensitive marker of treatment resistance and of the immune/inflammatory response in that illness. Biol Psychiatry, 1997, 42, 349-358.

19. McLoughlin IJ, Hodge SJ: Zinc in depressive disorder. Acta Psychiatr Scand, 1990, 82, 451-453.

20. Młyniec K, Nowak G: Zinc deficiency induces depression-like behavior in the tail suspension test in mice. Pharmacol Rep, 2012, 64, in press.

21. Nakashima AS, Dyck RH: Zinc and cortical plasticity. Brain Res Rev, 2009, 59, 347-373.

22. Nowak G, Siwek M, Dudek D, Zięba A, Pilc A: Effect of zinc supplementation on antidepressant therapy in unipolar depression: a preliminary placebo-controlled study. Pol J Pharmacol, 2003, 55, 1143-1147.

23. Nowak G, Szewczyk B, Pilc A: Zinc and depression. An update. Pharmacol Rep, 2005, 57, 713-718.

24. Nowak G, Szewczyk B, Wierońska JM, Brański P, Pałucha A, Pilc A, Sadlik K, Piekoszewski W: Antidepressant-like effects of acute and chronic treatment with zinc in forced swim test and olfactory bulbectomy model in rats. Brain Res Bull, 2003, 61, 159-164.

25. Nowak G, Szewczyk B: Mechanisms contributing to antidepressant zinc actions. Pol J Pharmacol, 2002, 54, 587-592.

26. Opoka W, Sowa-Kućma M, Stachowicz K, Ostachowicz B, Szlósarczyk M, Stypuła A, Młyniec K et al.: Early life time zinc supplementation protects zinc-deficient dietinduced alterations. Pharmacol Rep, 2010, 62, 1211-1217. 
27. Paoletti P, Ascher P, Neyton J: High-affinity zinc inhibition of NMDA NR1-NR2 receptors. J Neurosci, 1997, 17, 5711-5725.

28. Partyka A, Jastrzębska-Więsek M, Szewczyk B, Stachowicz K, Sławińska A, Poleszak E, Doboszewska $\mathrm{U}$ et al.: Anxiolytic-like activity of zinc in rodent tests. Pharmacol Rep, 2011, 63, 1050-1055.

29. Porsolt RD, Bertin A, Jalfre M: Behavioural despair in mice: a primary screening test for antidepressants. Arch Int Pharmacodyn Ther, 1977, 229, 327-336.

30. Rosa AO, Lin J, Calixto JB, Santos ARS, Rodrigues ALS: Involvement of NMDA receptors and L-argininenitric oxide pathway in the antidepressant-like effects of zinc in mice. Behav Brain Res, 2003, 144, 87-93.

31. Schlegel-Zawadzka M, Zięba A, Dudek D, Krośniak M, Szymaczek M, Nowak G: Effect of depression and of antidepressant therapy on serum zinc levels. Trace Elements in Man and Animals, 2000, 10, 607-610.

32. Siwek M, Dudek D, Paul JA, Sowa-Kućma M, Zięba A, Popik P, Pilc A, Nowak G: Zinc supplementation augments efficacy of imipramine in treatment resistant patients: A double blind, placebo-controlled study. J Affect Disord, 2009, 118, 187-195.

33. Siwek M, Dudek D, Schlegel-Zawadzka M, Morawska A, Piekoszewski W, Opoka W, Zięba A et al.: Serum zinc level in depressed patients during zinc supplementation of imipramine treatment. J Affect Disord, 2010, 126, 447-452.

34. Skolnick P, Layer RT, Popik P, Nowak G, Paul IA, Trullas R: Adaptation of N-methyl-D-aspartate (NMDA) receptors following antidepressant treatment: implications for the pharmacotherapy of depression. Pharmacopsychiatry, 1996, 29, 23-26.

35. Skolnick P, Popik P, Trullas R: Glutamate-based antidepressants: 20 years on. Trends Pharmacol Sci, 2009, 30, 563-569.

36. Sowa-Kućma M., Legutko B, Szewczyk B, Novak K, Znojek P, Poleszak E, Papp M et al.: Antidepressant-like activity of zinc: further behavioural and molecular evidence. J Neural Transm, 2008, 115, 1621-1628.

37. Suliman HB, Abdelrahim AI, Zakia AM, Shommein AM: Zinc deficiency in sheep: field cases. Trop Anim Health Prod, 1988, 20, 47-51.

38. Swaab DF, Bao AM, Lucassen PJ.: The stress system in the human brain in depression and neurodegeneration. Ageing Res Rev, 2005, 4, 141-194.

39. Szewczyk B, Brański P, Wierońska JM, Pałucha A, Pilc A, Nowak G: Interaction of zinc with antidepressants in the forced swimming test in mice. Pol J Pharmacol, 2002, 54, 681-685.

40. Szewczyk B, Poleszak E, Sowa-Kućma M, Siwek M, Dudek D, Ryszewska-Pokraśniewicz B, RadziwońZaleska M et al.: Antidepressant activity of zinc and magnesium in view of the current hypotheses of antidepressant action. Pharmacol Rep, 2008, 60, 588-599.

41. Szewczyk B, Poleszak E, Wlaź P, Wróbel A, Blicharska E, Cichy A, Dybała et al.: The involvement of serotonergic system in the antidepressant effect of zinc in the forced swim test. Prog Neuropsychopharmacol Biol Psychiatry, 2009, 33, 323-329.

42. Szymańska M, Budziszewska B, Jaworska-Feil L, Basta-Kaim A, Kubera M, Leśkiewicz M, Regulska M, Lason W: The effect of antidepressant drugs on the HPA axis activity, glucocorticoid receptor level ans FKBP51 concentration in prenatally stressed rats. Psychoneuroendocrinology, 2009, 34, 822-832.

43. Takeda A, Hirate M, Tamano H, Oku N: Release of glutamate and GABA in the hippocampus under zinc deficiency. J Neurosci Res, 2003, 72, 537-542.

44. Takeda A, Itoh H, Tamano H, Oku N: Responsiveness to kainate in young rats after 2-week zinc deprivation. BioMetals, 2006, 19, 565-572.

45. Takeda A, Tamano H, Itoh H, Oku N: Attenuation of abnormal glutamate release in zinc deficiency by zinc and Yokukansan. Neurochem Int, 2008, 53, 230-235.

46. Takeda A, Tamano H, Kan F, Hanajima T, Yamada H, Oku N: Enhancement of social isolation-induced aggressive behavior of young mice by zinc deficiency. Life Sci, 2008, 82, 909-914.

47. Takeda A, Tamano H, Kan F, Itoh H, Oku N: Anxietylike behavior of young rats after 2-week zinc deprivation. Behav Brain Res, 2007, 177, 1-6.

48. Takeda A, Tamano H, Oku N: Involvement of unusual glutamate release in kainate-induced seizures in zincdeficient adult rats. Epilepsy Res, 2005, 66, 137-143.

49. Takeda A, Tamano H: Insight into zinc signaling from dietary zinc deficiency. Brain Res Rev, 2009, 62, 33-44.

50. Takeda A, Tamano H: Zinc signaling through glucocorticoid and glutamate signaling in stressful circumstances. J Neurosci Res, 2010, 88, 3002-10.

51. Takeda A, Yamada K, Minami A, Nagano T, Oku N: Enhanced excitability of hipocampal mossy fibers and CA3 neurons under dietary zinc deficiency. Epilepsy Res, 2005, 63, 77-84.

52. Takeda A, Yamada K, Tamano H, Fuke S, Kawamura M, Oku N: Hippocampal calcium dyshomeostasis and longterm potentiation in 2-week zinc deficiency. Neurochem Int, 2008, 52, 241-246.

53. Tamano H, Kan F, Kawamura M, Oku N, Takeda A: Behavior in the forced swim test and neurochemical changes in the hippocampus in young rats after 2-week znic deprivation. Neurochem Int, 2009, 55, 536-541.

54. Trullas R, Skolnick P: Functional antagonists at the NMDA receptor complex exhibit antidepressant actions. Eur J Pharmacol, 1990, 185, 1-10.

55. Valee BL: The function of metallothionein. Neurochem Int, 1995, 27, 23-33.

56. Van Den Eede F, Claes SJ: Mechanisms of depression: role of the HPA axis. Drug Discov Today, 2004, 1, 413-418.

57. Watanabe M, Tamano H, Kikuchi T, Takeda A: Susceptibility to stress in young rats after 2-week zinc deprivation. Neurochem Int, 2010, 56, 410-416.

Received: October 10, 2011; in the revised form: January 30 , 2012; accepted: February 14, 2012. 